\title{
LUMBAR SPINAL STENOSIS: EVALUATION OF PAIN AND LIFE QUALITY AFTER SURGICAL TREATMENT
}

\author{
ESTENOSE DE CANAL LOMBAR: AVALIAÇÃO DE DOR E QUALIDADE DE VIDA APÓS \\ TRATAMENTO CIRÚRGICO
}

\section{ESTENOSIS DE CANAL LUMBAR: EVALUACIÓN DEL DOLOR Y DE LA CALIDAD DE VIDA DESPUÉS DE TRATAMIENTO QUIRÚRGICO}

Gustavo Alvarenga, ${ }^{1}$ Joäo Otávio Araújo Rotini, ${ }^{1}$ Leonardo Yukio Jorge Asano, ${ }^{1}$ Vinícius Alves de Andrade, ${ }^{1}$ André Evaristo Marcondes Cesar, ${ }^{1}$ Edgar Santiago Valesin Filho, ${ }^{1}$ Luciano Miller Reis Rodrigues ${ }^{1}$

1. Faculdade de Medicina do ABC, Spine Surgery Group, Santo André, SP, Brazil.

\begin{abstract}
Objective: The objective of this study was to present an analysis of progression of the quality of life and pain in patients undergoing surgical treatment of LSS and the potential correlations between individual factors and the clinical outcome observed. Methods: We studied 111 patients undergoing surgical treatment of LSS from January 2009 to December 2011 using the functional capacity (ODI) and pain (VAS) questionnaires. The preoperative data were compared statistically with the results obtained during the postoperative follow-up at one month, six months, one year, and two years. Results: The population consisted of 60 men and 51 women. The mean age was 61.16 years at the time of surgery, $33.33 \%$ were 60 years or older. When the questionnaires were applied, we found improvement in the progressive disability assessment with a mean drop of $23.65 \mathrm{ODI}$ points after 6 months of the surgical treatment and 27.47 at the end of one year of surgery compared to preoperative for this scale. There was a decline of 3.84 points (mean) in the VAS at first postoperative month. Conclusion: Surgical treatment of LSS presented favorable postoperative evolution in a 2-year follow-up regarding pain and quality of life through VAS and ODI. Level of Evidence IV; Case series.
\end{abstract}

Keywords: Spinal stenosis; Surgery; Quality of life; Pain.

RESUMO

Objetivo: O objetivo deste estudo foi apresentar uma análise evolutiva da qualidade de vida e da dor em pacientes submetidos ao tratamento cirúrgico da ECL, e possíveis correlações entre fatores individuais e o desfecho clínico observado. Métodos: Foram avaliados 111 pacientes submetidos ao tratamento cirúrgico da ECL, no período de Janeiro de 2009 a Dezembro de 2011, através de questionários de capacidade funcional (ODI) e dor (EVA). Os dados do período pré-operatório foram comparados estatisticamente com os resultados obtidos durante o seguimento pós-operatório de um mês, seis meses, um ano e dois anos. Resultados: A população foi constituída de 60 homens e 51 mulheres. A média de idade foi de 61,16 anos no momento da cirurgia, 33,33\% tinham 60 anos ou mais. Aplicados os questionários, encontramos melhora na avaliação progressiva da incapacidade, com uma queda média de 23,65 pontos do ODI após 6 meses do tratamento cirúrgico e de 27,47 ao final de um ano da cirurgia, em comparação com os valores de pontuação pré-operatória para esta escala. Houve um declínio de 3,84 pontos (média) na EVA já no primeiro mês de pós-operatório. Conclusão: 0 tratamento cirúrgico da ECL apresentou evolução pós-operatória favorável em acompanhamento de 2 anos, em análise de dor e qualidade de vida através de VAS e ODI. Nível de Evidência IV; Série de casos.

Descritores: Estenose espinal; Cirurgia; Qualidade de vida; Dor.

\section{RESUMEN}

Objetivo: El objetivo de este estudio fue presentar un análisis evolutivo de la calidad de vida y del dolor en pacientes sometidos a tratamiento quirúrgico de la ECL y posibles correlaciones entre factores individuales y el desenlace clínico observado. Métodos: Se evaluaron 111 pacientes sometidos al tratamiento quirúrgico de la ECL en el período de enero de 2009 a diciembre de 2011 a través de cuestionarios de capacidad funcional (ODI) y dolor (EVA). Los datos del período preoperatorio se compararon estadísticamente con los resultados obtenidos durante el seguimiento postoperatorio de un mes, seis meses, un año y dos años. Resultados: La población del estudio consistió en 60 hombres y 51 mujeres. La edad promedio fue de 61,16 años en el momento de la cirugía, el 33,33\% tenían 60 años o más. Cuando los cuestionarios fueron aplicados, encontramos una mejora en la evaluación de la incapacidad progresiva, con una caída media de 23,65 puntos del ODI después de 6 meses del tratamiento quirúrgico y de 27,47 al final de un año de la cirugía, en comparación con los valores de puntuación preoperatoria para esta escala. Se observó un descenso de 3,84 puntos (promedio) en la EVA ya en el primer mes de postoperatorio. Conclusión: El tratamiento quirúrgico de ECL presentó evolución postoperatoria favorable en el seguimiento de dos años con respecto al análisis de dolor y a la calidad de vida a través de EVA y ODI. Nivel de Evidencia IV; Serie de casos.

Descriptores: Estenosis espinal; Cirugía; Calidad de vida; Dolor. 


\section{INTRODUCTION}

Lumbar spinal stenosis (LSS) is a painful and potentially disabling condition affecting mainly the elderly population ${ }^{1}$ and considered the principal indication for spine surgery in patients over 65 years of age in the United States. ${ }^{2}$ Although its exact incidence in unknown, it is estimated to affect between three and twelve out of every 100,000 people over 65 years of age annually. ${ }^{3,4}$ LSS is the result of a narrowing of the canal that causes confinement of the neural structures by the spinal bones and the adjacent soft structures. ${ }^{5}$ It may involve the central canal, the lateral recess, the foramens, or even a combination of these. ${ }^{3}$ One of the symptoms is intermittent neurogenic claudication, the main cause of impaired mobility and loss of independence, compromising the quality of life of the elderly. ${ }^{6}$

The various forms of conservative treatment show progressive improvement in 15 to $43 \%$ of patients during follow-up of from 1 to 5 years. ${ }^{7}$ In the absence of improved symptoms with proper prolonged treatment or when there is progressive deterioration of the neurological function, surgery is indicated to improve patient quality of life. ${ }^{4}$ Decompression of lumbar stenosis is associated with arthrodesis of the level when associated degenerative segmental instability exists. ${ }^{5,8}$ Fixation, when correctly indicated, improved the outcomes from stenosis surgeries in long-term assessments, ${ }^{9}$ but there is still doubt around which factors can influence the results of surgeries for lumbar spinal stenosis. ${ }^{10}$

The objective of this study was to present an evolutive analysis of the quality of life and of pain in patients who underwent surgical treatment for LSS using questionnaires administered both pre- and postoperatively. In this analysis, we sought to define possible correlations between individual factors and the clinical outcomes observed.

\section{METHODS}

After approval by the Institutional Review Board (CAAE: 13842913.5.0000.0082), 111 patients who had undergone surgical treatment for LSS during the period from January 2009 to December 2011 were studied. All the patients signed the Informed Consent Form. They were assessed using clinical methods and complementary exams, such as simple and dynamic radiographs and magnetic resonance imaging (MRI), and diagnosed with LSS. Outpatient follow-up was performed by the same medical team during the period at the spinal surgery service of the Hospital Estadual Mário Covas, in Santo André São Paulo. After outpatient follow-up and conservative treatment, when failure of the implemented therapy was observed, the patients were submitted to surgical treatment. Cases in which the preoperative evaluation did not indicate segmental instability were submitted exclusively to decompression, while patients who presented associated instability underwent decompression surgery and lumbar arthrodesis, according to clinical and radiographic criteria presented in the literature. ${ }^{11}$

Functional capacity (Oswestry Disability Index - ODI) and pain (Visual Analog Scale - VAS) questionnaires were administered in the preoperative period and during postoperative follow-up at one month, six months, one year, and two years. The questionnaires were applied by two orthopedists specialized in spinal surgery, members of the Spine Group of the Faculdade de Medicina do ABC, who also conducted the pre- and postoperative clinical evaluations.

The ODI is a questionnaire aimed at measuring disability, based on social and physical limitations resulting from the condition being treated. It contains 10 questions that contemplate different daily activities. ${ }^{12,13}$ The VAS is a simplified, subjective assessment tool using an analog scale in which the patient assesses and classifies their pain by assigning a score from zero to ten. ${ }^{14}$ We also observed the variables of sex, age, smoking, number of levels operated, return to work, and whether the patients would undergo surgery again to prospectively evaluate possible interference from these individual factors in postoperative clinical evolution. Only patients with degenerative diseases were included in this study, regardless of age. Patients with tumors, infections, fractures, surgical revisions, cases in which the questionnaires were not administered properly, and cases lost to follow-up were excluded from the study.

\section{Statistical methodology}

We used Stata 11.0 software. The qualitative variables were described using frequencies and percentages. Means and confidence intervals were used to describe the quantitative variables. The Kruskal-Wallis test was used to analyze the association between quality of life and surgical levels and the Mann-Whitney test was used for the associations between quality of life and return to work, smoking, and satisfaction. The level of significance considered was 95\%.

\section{RESULTS}

One-hundred and eleven patients out of a total of 129 were included in the study (Table 1). The population consisted of 60 men $(54.05 \%)$ and 51 women (45.95\%). The mean age was 61.16 years at the time of surgery, ranging from 55 to 84 years of age, with 37 patients aged 60 or above (33.33\%) and 74 patients under 60 years of age (66.67\%). Only 22 patients (19.82\%) were smokers. All patients underwent surgical treatment following conservative treatment of varying duration (mean of six months) due to the severity of symptoms and the clinical evolution observed. Decompression and posterolateral arthrodesis was performed in 52 patients (46.85\%), complementary interbody fusion (TLIF) in 36 patients (32.43\%), and simple decompression without arthrodesis in 23 patients $(20.72 \%)$. The indication of the levels to be operated was established according to clinical findings and in agreement with the imaging tests. Thus, a one-level approach was performed in 55 patients (49.55\%), a two-level approach in 38 patients (34.32\%), and a three-level approach in 18 patients (16.22\%). We observed that 35 patients $(31.5 \%)$ were retired, 7 of whom were under 60 years of age. Of the 76 who were working (46 men and 30 women), 42 (55.26\%) returned to work and 34 (44.74\%) did not. Analyzing the return to work results by sex, we observed that 21 (45.65\%) of the 46 men and 21 (70\%) of the 30 women returned to their former jobs. When asked if they would undergo surgery again, 92 (82.88\%) answered yes and 19 (17.12\%) answered no.

When the questionnaires were applied, we found progressive improvement in disability through the ODI. We observed a progressive drop in the mean values of the ODI questionnaire as compared

Table 1. Characterization of the sample.

\begin{tabular}{|c|c|c|}
\hline Characteristics & $\begin{array}{c}\mathbf{N} \text { (number of } \\
\text { patients) }\end{array}$ & $\%$ \\
\hline \multicolumn{3}{|l|}{ Sex } \\
\hline Male & 60 & 54.05 \\
\hline Female & 51 & 45.95 \\
\hline \multicolumn{3}{|l|}{ Age (mean: 61.16 years) } \\
\hline 60 years or above & 37 & 33.33 \\
\hline Up to 59 years & 74 & 66.67 \\
\hline \multicolumn{3}{|l|}{ Smoker } \\
\hline No & 89 & 80.18 \\
\hline Yes & 22 & 19.82 \\
\hline \multicolumn{3}{|l|}{ Surgical Technique } \\
\hline Decompression with arthrodesis & 52 & 46.85 \\
\hline Complementary interbody fusion & 36 & 32.43 \\
\hline Decompression without arthrodesis & 23 & 20.72 \\
\hline \multicolumn{3}{|l|}{ Levels affected } \\
\hline 1 & 55 & 49.55 \\
\hline 2 & 38 & 34.23 \\
\hline 3 & 18 & 16.22 \\
\hline \multicolumn{3}{|l|}{ Return to work } \\
\hline No & 34 & 44.74 \\
\hline Yes & 42 & 55.26 \\
\hline \multicolumn{3}{|l|}{ Satisfaction } \\
\hline No & 19 & 17.12 \\
\hline Yes & 92 & 82.88 \\
\hline
\end{tabular}


to the preoperative score: a reduction from the initial 65.98 points to 57.73 after one month, 42.33 after six months, 38.22 after one year, and 38.22 after two years (Figure 1). The mean pain score measured using the VAS scale moved from 8.73 in the preoperative period to 4.89 after one month, to 4.22 after six months, 3.83 after one year, and 3.88 after two years (Figure 2).

\section{Statistical correlation results}

We did not observe any statistically significant differences in our prospective analysis of the ODI and VAS scores in relation to the sex of the patients, when studied separately. Analyzing the scores of patients under 60 years of age, we saw an improvement in the mean values of pain and disability, but we did not observe any statistically significant differences in the prospective analysis of the results by age group (Table 2).

There were no statistically significant differences between the scores of smoking and non-smoking patients in this comparative analysis (Table 3 ).

As regards the surgical technique used and the number of levels surgically treated, we observed that the ODI and VAS scores of patients who underwent surgical treatment improved, but without statistical differences between them (Table 4) when the variables were studied individually in the prospective analysis.

There were no statistically significant differences in the evolutive analysis between patients who returned to work and those who did not in relation to the pre- and post-operative periods (Table 5). In our assessment of the ODI and VAS scores of the patients who answered that they would undergo surgery again and of those who said they would not, we did not observe any statistically significant

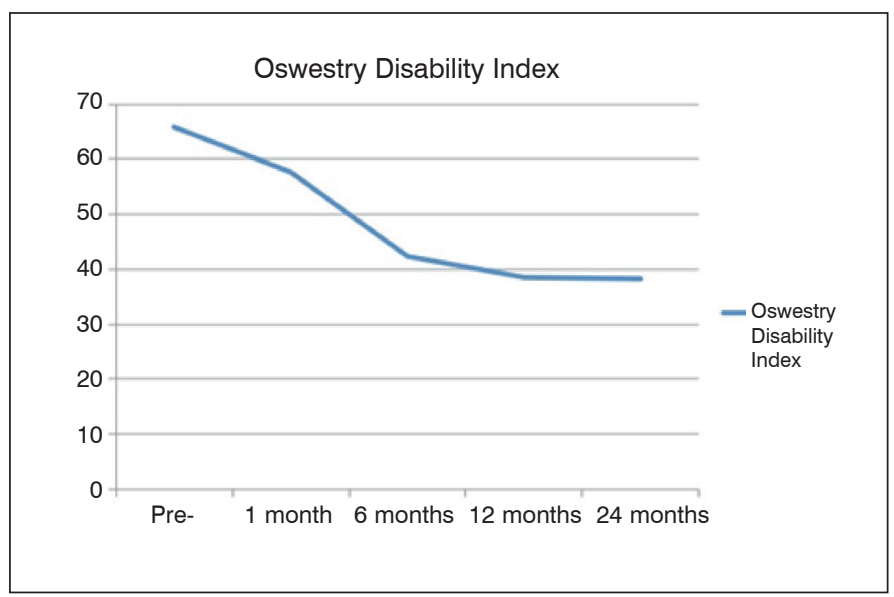

Figure 1. ODI questionnaire during patient follow-up.

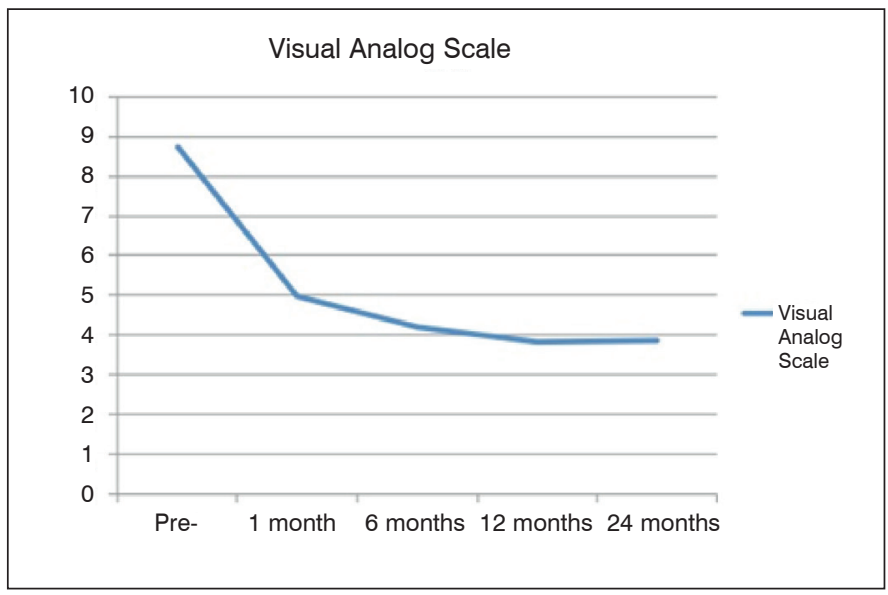

Figure 2. VAS questionnaire during patient follow-up. interference in the comparative analysis of the results at the different observation points (Table 6). In the comparative evolutive analysis between the ODI and VAS scores, we observed a similar pattern of decline in the post-operative period at 1 and 6 months, trending towards stabilization after 1 and 2 years of post-surgical outpatient follow-up. Thus, we studied the variables of age, sex, smoking, surgical technique, number of levels operated, return to work, and personal satisfaction, individually in relation to the ODI and VAS

Table 2. Association between age and ODI and VAS scores

\begin{tabular}{|c|c|c|c|}
\hline & \multicolumn{2}{|c|}{ Age group } & \multirow{3}{*}{$\mathbf{p}^{*}$} \\
\hline & Up to 59 years & 60 years or above & \\
\hline & \multicolumn{2}{|c|}{ median (CI95\%) } & \\
\hline \multicolumn{4}{|l|}{ ODI } \\
\hline Preoperative & $67.3(62.5-70)$ & $70(67.5-74.9)$ & 0.331 \\
\hline After 1 month & $62.5(60-67.5)$ & $62.5(45.1-70)$ & 0.747 \\
\hline After 6 months & $45(40.2-53.8)$ & $32.5(27.6-40)$ & 0.044 \\
\hline After 1 year & $41(35.1-47.5)$ & $32.5(30-39.9)$ & 0.217 \\
\hline After 2 years & $40(32.5-48)$ & $32.5(25-40)$ & 0.102 \\
\hline \multicolumn{4}{|l|}{ VAS } \\
\hline Preoperative & $10(9-10)$ & $10(9-10)$ & 0.657 \\
\hline After 1 month & $5.3(4-6)$ & $4(3-6)$ & 0.128 \\
\hline After 6 months & $5(3.5-5)$ & $3(2.5-4.9)$ & 0.141 \\
\hline After 1 year & $4(4-5)$ & $3(2-4.9)$ & 0.179 \\
\hline After 2 years & $4(4-5)$ & $3(2-5)$ & 0.293 \\
\hline
\end{tabular}

Cl95\%: Confidence Interval of $95 \%$; *Kruskal-Wallis

Table 3. Association between smoking and ODI and VAS scores.

\begin{tabular}{c|c|c|c}
\hline \multirow{2}{*}{ ODI } & \multicolumn{2}{|c|}{ Smoking } & \multirow{2}{*}{ Yes } \\
\cline { 2 - 3 } & \multirow{2}{*}{ median (CI95\%) } & \\
\cline { 2 - 3 } & & & \\
\hline Preoperative & $66(59.8-70.7)$ & $70(65-70)$ & 0.643 \\
\hline After 1 month & $47.8(30-60.4)$ & $65(60.7-70)$ & 0.004 \\
\hline After 6 months & $37.5(22.3-46.1)$ & $42.5(35-50)$ & 0.120 \\
\hline After 1 year & $33.8(22.5-47.5)$ & $40(32.5-42.5)$ & 0.458 \\
\hline After 2 years & $30(20-45)$ & $40(32.5-45.1)$ & 0.233 \\
\hline VAS & & & \\
\hline Preoperative & $9.5(7.9-10)$ & $10(9-10)$ & 0.430 \\
\hline After 1 month & $5.5(3-7)$ & $5(4-6)$ & 0.867 \\
\hline After 6 months & $4.25(2-5)$ & $4(3.5-5)$ & 0.660 \\
\hline After 1 year & $4(2-5)$ & $4(3-5)$ & 0.922 \\
\hline After 2 years & $4(2.9-4.1)$ & $4(3-5)$ & 0.309 \\
\hline
\end{tabular}

C195\%: Confidence interval of 95\%; *Mann-Whitney

Table 4. Association between the levels operated and the ODI and VAS scores.

\begin{tabular}{c|c|c|c|c}
\hline \multirow{2}{*}{} & \multicolumn{3}{|c|}{ Surgical levels } & \\
\cline { 2 - 5 } & \multicolumn{3}{|c|}{ median (CI95\%) } & \multirow{2}{*}{$\mathbf{p}^{*}$} \\
\cline { 2 - 5 } ODI & \multicolumn{3}{|c|}{$\mathbf{3}$} & \\
\hline Preoperative & $68(61.4-70)$ & $67.5(60.8-73.9)$ & $70(64.7-78.5)$ & 0.399 \\
\hline After 1 month & $62.5(54.3-67.6)$ & $63.3(58.5-70)$ & $58.7(45-74.12)$ & 0.945 \\
\hline After 6 months & $45(36.8-52.1)$ & $38.8(28.5-46.5)$ & $35(30-59.3)$ & 0.496 \\
\hline After 1 year & $40(30-45)$ & $35(28.5-45.4)$ & $38.8(30.7-59.2)$ & 0.536 \\
\hline After 2 years & $40(30-46.8)$ & $30(24.06-42.4)$ & $42.5(32.5-55)$ & 0.149 \\
\hline VAS & & & & \\
\hline Preoperative & $10(9-10)$ & $10(8.4-10)$ & $10(7.1-10)$ & 0.998 \\
\hline After 1 month & $6(4-7)$ & $4.5(3-6)$ & $4(2-6)$ & 0.075 \\
\hline After 6 months & $5(3.5-5.3)$ & $3(2-5)$ & $4.5(3.1-5)$ & 0.216 \\
\hline After 1 year & $4(3-5)$ & $3(2-4)$ & $5(2.4-6)$ & 0.052 \\
\hline After 2 years & $4(3-5)$ & $3.25(3-5)$ & $4.5(3.3-6)$ & 0.328 \\
\hline
\end{tabular}

C195\%: Confidence Interval of $95 \%$; ${ }^{*}$ Kruskal-Wallis 
Table 5. Association between return to work and ODI and VAS scores.

\begin{tabular}{|c|c|c|c|}
\hline & \multicolumn{2}{|c|}{ Return to work } & \multirow{3}{*}{$\mathrm{p}^{*}$} \\
\hline & Yes & No & \\
\hline & \multicolumn{2}{|c|}{ median (Cl95\%) } & \\
\hline \multicolumn{4}{|l|}{ ODI } \\
\hline Preoperative & $62.25(57.9-70)$ & $67.8(62.5-72.5)$ & 0.175 \\
\hline After 1 month & $65(60-70)$ & $61.8(49.5-68.1)$ & 0.916 \\
\hline After 6 months & $42.5(35.4-49.6)$ & $45.5(31.9-60.5)$ & 0.590 \\
\hline After 1 year & $38.5(27.6-45)$ & $41.3(30-51.1)$ & 0.357 \\
\hline After 2 years & $35(30-47.9)$ & $41.25(27.5-52)$ & 0.960 \\
\hline \multicolumn{4}{|l|}{ VAS } \\
\hline Preoperative & $10(8.5-10)$ & $9(8.9-10)$ & 0.800 \\
\hline After 1 month & $5(4-6)$ & $5.8(3-6.2)$ & 0.621 \\
\hline After 6 months & $4(3-5)$ & $5(3.4-6)$ & 0.537 \\
\hline After 1 year & $3.8(3-4.9)$ & $5(3.8-5.1)$ & 0.187 \\
\hline After 2 years & $3.5(2-4.9)$ & $4(3.4-5)$ & 0.250 \\
\hline
\end{tabular}

C195\%: Confidence Interval of 95\%; *Kruskal-Wallis

Table 6. Association between satisfaction and ODI and VAS scores.

\begin{tabular}{|c|c|c|c|}
\hline & \multicolumn{2}{|c|}{ Satisfaction } & \multirow{3}{*}{$p^{*}$} \\
\hline & Yes & No & \\
\hline & \multicolumn{2}{|c|}{ median (Cl95\%) } & \\
\hline \multicolumn{4}{|l|}{ ODI } \\
\hline Preoperative & $69(64.1-70)$ & $70(59.4-75)$ & 0.897 \\
\hline After 1 month & $62.5(60-67.5)$ & $62.5(46.2-78.3)$ & 0.456 \\
\hline After 6 months & $42.5(35-45.9)$ & $42.5(30.9-67.7)$ & 0.323 \\
\hline After 1 year & $36(30-40)$ & $42.5(30.2-61.5)$ & 0.308 \\
\hline After 2 years & $35(30-40)$ & $42.5(35-54.45)$ & 0.218 \\
\hline \multicolumn{4}{|l|}{ VAS } \\
\hline Preoperative & $10(9-10)$ & $10(7.5-10)$ & 0.768 \\
\hline After 1 month & $5(4-6)$ & $4(3-8.2)$ & 0.498 \\
\hline After 6 months & $4(3.1-5)$ & $4.5(3-6)$ & 0.797 \\
\hline After 1 year & $4(3-4.9)$ & $5(3-5)$ & 0.223 \\
\hline After 2 years & $4(3-5)$ & $4(3-5.3)$ & 0.424 \\
\hline
\end{tabular}

Cl95\%: Confidence Interval of 95\%; *Mann-Whitney.

scores in the preoperative and evolutive postoperative periods. We did not find statistically significant differences in any of the cases and consequently we could not attribute individually determinant factors to any of the study variables for different outcomes in relation to the pain (VAS) and disability (ODI) results observed.

\section{DISCUSSION}

In this study, an evolutive analysis of the quality of life and pain of patients submitted to surgical treatment for lumbar spinal stenosis was conducted and showed favorable postoperative evolution.

Degenerative LSS is a chronic condition that affects elderly patients who many times have associated diseases that contribute to their limitations and the intensity of their pain. According to the literature, patients with lumbar spinal stenosis, become symptomatic and undergo decompression around the fifth or sixth decade of life. ${ }^{15}$ In most cases where surgical treatment is involved, the mean age is 65 years or greater and the interventionist therapy is motivated by the failure of clinical treatment or a worsening of symptoms. ${ }^{16}$ In our analysis, the mean patient age at the time of surgery was 61.16 years. As compared to a similar study in the national literature, Valesin et al. ${ }^{17}$ observed a mean age of 66.5 years in a range of from 45 to 85 years of age. In their study involving 1764 patients who underwent surgical treatment for lumbar spinal stenosis, Sobottke et $\mathrm{al}^{18}$ divided the patients into 3 age groups - less than 65 years, from 64 to 75 years, and 75 years or above - for an analysis of complications and clinical results. The authors reported that age did not interfere with the risk of surgical complications or levels of patient satisfaction with the surgical procedure to which they were submitted, in the postoperative follow-up. According to a study by Li et al., even in patients over 75 years of age in satisfactory clinical condition, surgery for lumbar spinal stenosis is a safe and justifiable treatment option for elderly patients when clinical treatment fails. ${ }^{19}$ According to Kalff et al. ${ }^{16}$ in a study including 55,793 patients over 65 years of age in treatment for lumbar spinal stenosis, there is currently no specific evidence-based recommendation for treatment of stenosis in the elderly because of the absence of adequate randomized clinical trials available for this condition in this age group. According to $\mathrm{Li}^{19}$ the comorbidities presented by elderly patients submitted to surgical treatment for lumbar spinal stenosis, and not necessarily their age, cause greater risks of adverse effects and complications in the surgical outcome. In our study, we observed that age did not influence the pain and disability results, possibly showing that, in these patients, the main limiting factor was actually the vertebral pathology, although specific questionnaires about other degenerative orthopedic comorbidities, or even clinical conditions, were not administered.

Although some authors report a slight male predominance in studies of patients submitted to surgical treatment for LSS, ${ }^{20}$ there is no consensus about the exact proportions of this distribution in surgical evaluations in the literature, since other factors are involved in the indication, such as regional peculiarities and ethnocultural variables, as well as work activities that could contribute to the worsening of symptoms. According to Katz, ${ }^{21}$ women who undergo laminectomy to treat LSS do so at substantially lower functional levels than men, and they also present greater clinical improvement in the comparative evaluation of the sexes. The authors point out that women possibly undergo surgical treatment in more advanced stages in the course of their illnesses and that, possibly, this happens because of individual preference, differences in accessibility to healthcare services, in addition to specific demographic and clinical factors. According to Hall, ${ }^{22}$ women with LSS exceed men at a ratio of $3: 1$ to $5: 1$. The preponderance of women may be related to hormonal changes and consequent ligamentous laxity, as well as to higher incidences of spondylolisthesis in females. This study found a predominance of men at $54.1 \%$. However, in our analysis of the VAS and ODI in relation to sex, we did not observe significant correlations or differences that could attribute changes in the clinical results to the sex of the patient.

The negative effects of smoking on the spine and on the results of spinal surgery have been shown. Smoking increases the risk of lumbar disc degeneration and inhibits spinal arthrodesis. $^{23,24}$ In a study ${ }^{23}$ related to smoking and the surgical outcome of decompression and lumbar arthrodesis procedures, significantly lower functional improvement was observed in the SF-36 and ODI questionnaires with intervention in smokers. Sandén et al. ${ }^{24}$ confirmed that smoking is an important predictor of results 2 years following lumbar spinal stenosis surgery. Smokers have less improvement in the quality of life following surgery than non-smokers. In our study, there was not a significant difference in the analysis of the quality of life and pain scores of smokers as compared to non-smokers. This observation possibly indicates that there are multiple factors associated with the postoperative evolution of LSS that interfere with the control of progressive pain and disability and that the analysis of a single isolated factor may not determine the outcome exclusively.

The population studied showed homogenous improvement in the level of quality of life (ODI) and pain (VAS) without any influence from the number of levels operated. In agreement with the results in the literature, we believe that a precise indication is fundamentally important to favorable results in the surgical treatment of this condition. The studies by Glassman et al. ${ }^{25}$ Valesin Filho et al., ${ }^{17}$ and Godfryd et al. ${ }^{26}$ observed a statistical difference in the quality of life in relation to the number of arthrodesed levels. In view of this, we can conclude that when well-indicated, surgical treatment may present favorable results regardless of the scope of the surgery, although there is no consensus around this subject in the literature. 
The ODI score categories are minimal disability $(0-20)$, moderate disability $(21-40)$, severe disability $(41-60)$, crippled (61 - 80), and bed-bound (81-100). ${ }^{12,13}$ Six months following surgical treatment, we observed a mean decrease of 23.65 points (65.98 - 42.33) when compared to the preoperative score values for this scale. After one year, there was a mean decrease in the ODI from the preoperative score of 65.98 to 38.51, i.e., most of the patients classified as crippled before surgery had moved to the moderate disability category one year after surgery. Hagg et al. ${ }^{27}$ considered a decrease of 10 points from the preoperative score over the same one-year period to be good results. According to Copay et al., ${ }^{28}$ a difference of 12.8 points in the analysis of evolutive disability after six months is considered a satisfactory surgical outcome. Two years following treatment, we observed a regression of 42 points in the mean ODI values. According to the study by Ostelo et al., ${ }^{29}$ a reduction of 30 percent in comparison to the preoperative, in comparison to the preoperative functional status score indicates a satisfactory surgical outcome. One possible hypothesis for the elevated improvement in the ODI levels in the present study is the fact that our patients were severely disabled. The chronic profile, the difficult and slow process of access to the public specialized healthcare system, and even the expectations regarding the procedure may have contributed to a more favorable outcome.

On the other hand, the VAS scale by definition has grading levels from 0 to 10 points, indicating progressive pain intensity. We observed a mean decline of 3.84 points $(8.73-4.89)$ in the first month following surgery. According to Carvalho et al., ${ }^{30}$ an improvement of 2 points in this period is considered a good outcome. The evolutive variation in pain ranged from strong $(7-9)$ to mild $(1-3)$ after 1 year. Mean points varied sequentially from 8.73 in the preoperative period to 4.2 after six months, to 3.83 after one year, to 3.88 after two years. According to Fekete et al., ${ }^{31}$ most surgical spinal procedures reduce pain, but rarely are they able to eliminate it completely. Thus, according to the authors, a report of success or favorable surgical outcome in painful spinal ailments should be redefined to reflect a more realistic objective of achieving a clinical condition equivalent to an "acceptable state of symptomatology" for the patient. For degenerative diseases in general, the authors assign VAS values equal to or less than 3 points for this observation. In our study, comparative analysis of mean ODI and VAS when paired did not yield a statistically significant difference at the different observation points. However, at six months we observed a tendency towards the leveling out of clinical improvement, with the stabilization of progressive improvement in the levels of disability (ODI) and pain (VAS) during follow-ups from six months to two years. Most studies follow a standard of a minimum of two years of follow-up for results evaluation. According to Melancia et al., ${ }^{32}$ there is currently Class $1 \mathrm{~B}$ evidence indicating that surgery is beneficial for the treatment of lumbar spinal stenosis, at least in the short term. The parameters present gradual improvement during the first year of follow-up and then tend to stabilize, maintaining constant indices after two years and showing both the efficacy of the procedure and good maintenance results, in agreement with prospective long-term evaluations in the literature. ${ }^{33}$

In this study we found a $55.26 \%$ rate of return to work, while Pihlajamäki et al. ${ }^{34}$ observed a rate of $36.5 \%$. In a study involving 439 patients who underwent surgery for LSS, Airaksenen ${ }^{35}$ observed that return to work can be considered an indicator of a favorable surgical outcome and that the ability to perform professional activities prior to surgery is predictive factor for a good outcome. According to the authors, of the 86 patients previously actively working, $52(60.46 \%)$ returned to work. In the study by Herno et al., ${ }^{36} 37 \%$ of the women and $41 \%$ of the men returned to work. Truszczyńska et al. ${ }^{37}$ reported that a total of $75 \%$ of patients operated for LSS did not return to their preoperative jobs. According to the authors, difficulty returning to work and reduced quality of life are associated with the female sex, a lower educational level, strenuous physical work, and low income. However, we believe that analysis of return to work is a complex issue involving regional and socio-economic peculiarities that may hamper comparative evaluations in certain areas.

This study aims to corroborate strong evidence of the favorable impact of carefully indicated surgical treatment of LSS on patient perception in their subjective assessment of pain and disability. We found that most of the patients (82.88\%) were satisfied with the results in responding that they would undergo surgery again. We did not observe statistically significant correlations in our analysis of pain and quality of life in relation to the patients' personal satisfaction. Kalbarczyk ${ }^{38}$ reported a satisfaction rate of $91 \%$ in a population of 148 elderly patients over 70 years of age submitted to surgical treatment of LSS. In a meta-analysis of more than 74 publications focused on surgical treatment of LSS, Turner $^{39}$ found a mean rate of satisfaction and favorable results of $64 \%$. According to Yamashita, ${ }^{40}$ patient personal satisfaction is correlated with the severity of symptoms, walking ability, and functional assessments in specific questionnaires. According to the authors, who observed 204 patients who underwent surgical treatment for LSS, personal satisfaction is much more related to the final functional results observed in the scores than in the variation of scores in each case. However, it was reported that patient satisfaction, although a valid analysis, does not allow us to distinguish objectively, nor does it reflect the individual clinical changes, with many subjective factors interfering in the evaluation. Gepstein et al. ${ }^{41}$ recommended that more information be supplied to the patient prior to the surgical procedure in order to reduce the gaps that still exist between expectations around and satisfaction with the intervention. Several other factors potentially interfered with the evolution of the patients, such as clinical comorbidities, the experience of the surgical team, the ASA anesthetic assessment, blood loss, and surgical time, among others, but were not in the scope of this study. ${ }^{42}$

\section{CONCLUSION}

The surgical treatment of LSS showed favorable postoperative evolution during follow-up of two years in an analysis of pain and quality of life of 111 patients based on the ODI and VAS. Several factors interfered with this process, however, we did not observe significant correlations when they were evaluated individually, pointing to the complexity of objectively defining factors that determine the outcome of this condition.

All authors declare no potential conflict of interest related to this article.

CONTRIBUTION OF THE AUTHORS: Each author made significant individual contributions to this manuscript. LYJA (0000-0002-8489-5256* and JOAR $(0000-0001-7263-0077)^{\star}$ conducted the bibliographical research. VAA $(0000-0002-5716-970 X)^{\star}$ and AEMC $(0000-0002-0148-4372)^{\star}$ administered the questionnaires. ESVF (0000-0002-1521-0989)* and GA (0000-0003-3556-073X)* were the main contributors to the writing of the manuscript and the statistical data analysis. LMRR (0000-0001-6891-5395)* reviewed the manuscript, approved the final article, and contributed with the intellectual concept of the study. *ORCID (Open Researcher and Contributor ID). 


\section{REFERENCES}

1. Arbit E, Pannullo S. Lumbar stenosis: A clinical review. Clin Orthop Relat Res. 2001:(384):137-43

2. TaylorVM, Deyo RA, Cherkin DC, KreuterW. Low back pain hospitalization. Recent United States trends and regional variations. Spine (Phila Pa 1976). 1994;19(11):1207-12.

3. Joaquim $A F$, Sansur CA, Hamilton DK, Shaffrey $\mathrm{Cl}$. Degenerative lumbar stenosis. Ara Neuropsiquiatr. 2009;67(2-B):553-8.

4. Zingg POZ, Boos N. Lumbar spinal stenosis. In: Boss N, Aebi M, editors. Disorders of the spine. Berlin: Springer-Verlag Heidelberg; 2008. p. 513-33.

5. Weinstein JN, Tosteson TD, Lurie JD, Tosteson ANA, Blood E, Hanscom B, et al. Surgical versus nonsurgical therapy for lumbar spinal stenosis. N Engl J Med. 2008;358(8):794-810.

6. Weiner DK. Office management of chronic pain in the elderly. Am J Med. 2007;120(4):306-15

7. Simotas AC. Nonoperative treatment for lumbar spinal stenosis. Clin Orthop Relat Res. $2001 ;(384): 153-61$

8. Deyo RA, Ciol MA, Cherkin DC, Loeser JD, Bigos SJ. Lumbar spinal fusion: a cohort study of complications, reoperations, and resource use in the medicare population. Spine (Phila Pa 1976). 1993;18(11):1463-70

9. Christensen FB. Lumbar spinal fusion. Outcome in relation to surgical methods, choice of implants and postoperative rehabilitation. Acta Orthop Scand. 2004:75(313):2-43.

10. Den Boer J, Oostendorp R, Beems T, Munneke M, Oerlemans M, Evers A. A systematic review of bio-psychosocial risk factors for an unfavourable outcome after lumbar disc surgery. Eur Spine J. 2006;15(5):527-36.

11. Curlee PM. Other disorders of the spine: Spine stenosis. In: Canale ST, Beatty JH, editors. Campbell's operative orthopaedics. 11th. Philadelphia: Mosby Elsevier; 2007. p. $2274-87$.

12. Fairbank JC, Pynsent PB. The Oswestry Disability Index. Spine (Phila Pa 1976). 2000:25(22):2940-52

13. Vigatto R, Alexandre NM, Correa Filho HR. Development of a Brazilian Portuguese version of the Oswestry Disability Index: cross-cultural adaptation, reliability, and validity. Spine (Phila Pa 1976). 2007:32(4):481-6.

14. Price DD, McGrath PA, Rafii A, Buckingham B. The validation of visual analogue scales as ratio scale measures for chronic and experimental pain. Pain. 1983;17(1):45-56.

15. Atlas SJ, Delitto A. Spinal stenosis: surgical versus nonsurgical treatment. Clin Orthop Relat Res. 2006:443:198-207.

16. Kalff R, Ewald C, Waschke A, Gobisch L, Hopf C. Degenerative lumbar spinal stenosis in older people: current treatment options. Dtsch Arztebl Int. 2013;110(37):613-23.

17. Valesin Filho ES, Ueno FH, Cabral LTB, Yonezaki AM, Nicolau RJ, Rodrigues LMR. Estudo prospectivo de avaliação de dor e incapacidade de pacientes operados de estenose de canal lombar com seguimento mínimo de dois anos. Rev Coluna/Columna. 2009;8(4):390-4.

18. Sobottke R, Aguayev E, Roder C, Eysel P, Delank SK, Zweig T. Predictors of surgical, general and follow-up complications in lumbar spinal stenosis relative to patient age as emerged from the Spine Tango Registry. Eur Spine J. 2012;21(3):411-7.

19. Li G, Patil CG, Lad SP, Ho C, Tian W, Boakye M. Effects of age and comorbidities on complication rates and adverse outcomes after lumbar laminectomy in elderly patients. Spine (Phila Pa 1976). 2008;33(11):1250-5.

20. Katz JN, Dalgas M, Stucki G, Lipson SJ. Diagnosis of lumbar spinal stenosis. Rheum Dis Clin North Am. 1994:20(2):471-83.

21. Katz JN, Wright EA, Guadagnoli E, Liang MH, Karlson EW, Cleary PD. Differences between men and women undergoing major orthopedic surgery for degenerative arthritis. Arthritis Rheum. 1994;37(5):687-94.

22. Hall S, Bartleson JD, Onoifrio BN, Baker HL Jr, Okazaki H, O’Duffy JD. Lumbar spinal stenosis: clinical features, diagnostic procedures, and results of surgical treatment in 68 patientes. Ann Intern Med. 1985;103(2):271-5.

23. Slover J, Abdu WA, Hanscom B, Weinstein JN. The impact of comorbidities on the change in short-form 36 and oswentry scores following lumbar spine surgery. Spine (Phila Pa 1976). 2006;31(17):1974-80

24. Sandén B, FFörsth $P$, Michaëlsson K. Smokers show less improvement than nonsmokers two years after surgery for lumbar spinal stenosis: a study of 4555 patients from the Swedish spine register. Spine (Phila Pa 1976). 2011;36(13):1059-64.

25. Glassman SD, Carreon LY, Dimar JR, Campbell MJ, Puno RM, Johnson JR. Clinical outcomes in older patients after posterolateral lumbar fusion. Spine J. 2007;7(5):547-51.

26. Gotfryd AO, Henrique GG, Poletto PR. Influência da extensão da artrodese lombossacra nos resultados clínicos e funcionais. Rev Coluna/Columna. 2012:11(1):13-6.

27. Hagg O, Fritzell P, Nordwall A. The clinical importance of changes in outcome scores after treatment for chronic low back pain. Eur Spine J. 2003;12(1):12-20.

28. Copay AG, Glassman SD, Subach BR, Berven S, Schuler TC, Carreon LY. Minimum clinically important difference in lumbar spine surgery patients: a choice of methods using the Oswestry Disability Index, Medical Outcomes Study questionnaire Short Form 36, and pain scales. Spine J. 2008;8(6):968-74.

29. Ostelo RW, Deyo RA, Stratford P, Waddell G, Croft P, Von Korff M, et al. Interpreting change scores for pain and functional status in low back pain: towards international consensus regarding minimal important change. Spine (Phila Pa 1976). 2008;33(1):90-4.

30. Carvalho DS, Kowacs PA. Avaliação da intensidade da dor. Migrâneas Cefaléias. 2006;9(4):164-8

31. Fekete TF, Haschtmann D, Kleinstuck F, Porchet F, Jeszenszky D, Mannion AF. What level of pain are patients happy to live with after surgery for lumbar degenerative disorders? Spine J. 2016;16(4):S12-8.

32. Melancia JL, Francisco AF, Antunes JL. Spinal stenosis. Handb Clin Neurol. 2014;119:541-9.

33. Foulongne $E$, Derrey $S$, Ould Silmane $M$, Levèque $S$, Tobenas $A C$, Dujardin $F$, et al. Lumbar spinal stenosis: which predictive factors of favorable functional results after decompressive laminectomy? Neurochirurgie. 2013;59(1):23-9.

34. Pihlajamäki H, Myllynen P, Böstman O. Return to work after posterolateral fusion with transpedicular instrumentation for spondylarthrosis of the lumbosacral spine. Ann Chir Gynaecol. 1996;85(1):63-6.

35. Airaksenen O, Herno A, Saari T. Surgical treatment of lumbar spinal stenosis: patients postoperative disability and working capacity. Eur Spine J. 1994;3(5):261-4.

36. Herno A, Airaksinen O, Saari T, Svomalainen O. Pre- and postoperative factors associated with return to work following surgery for lumbar spinal stenosis. Am $\mathrm{J}$ Ind Med. 1996;30(4):473-8.

37. Truszczyńska A, Rąpała K, Truszczyński O, Tarnowski A, Łukawski S. Return to work after spinal stenosis surgery and the patient's quality of life. Int J Occup Med Environ Health. 2013;26(3):394-400.

38. Kalbarczyk A, Lukes A, Seiler RW. Surgical treatment of lumbar spinal stenosis in the elderly. Acta Neurochir (Wien). 1998;140(7):637-41.

39. Turner JA, Ersek M, Herron L, Deyo R. Surgery for lumbar spinal stenosis. Attempted meta-analysis of the literature. Spine (Phila Pa 1976). 1992;17(1):1-8.

40. Yamashita K, Ohzono K, Hiroshima K. Patient satisfaction as an outcome measure after surgical treatment for lumbar spinal stenosis: testing the validity and discriminative ability in terms of symptoms and functional status. Spine (Phila Pa 1976). 2006;31(22):2602-8.

41. Gepstein R, Arinzon Z, Adunsky A, Folman Y. Decompression surgery for lumbar spinal stenosis in the elderly: preoperative expectations and postoperative satisfaction. Spinal Cord. 2016;44(7):427-31.

42. Dasenbrock HH, Clarke MJ, Witham TF, Sciubba DM, Gokaslan ZL, Bydon A. The impact of provider volume on the outcomes after surgery for lumbar spinal stenosis. Neurosurgery. 2012;70(6):1346-53. 